anatomy, physiology, pathology, and then and not till then is there given a description of the radiographic appearances. Then follows a section on what can be achieved by X-ray treatment.

Only 238 figures are shown, a very small number for such an encyclopædic book, but many of them are not reproduced sufficiently well to compare with the high standard of the text.

The author hopes that the book will be of value to students and to clinicians, so as to enable them to appreciate the value of $\mathrm{X}$-ray examinations. This is perhaps rather much to hope for in the already overburdened life of the student and of the clinician. To students of radiology, however, the book will prove of inestimable value. If every candidate for a radiological diploma uses this book as his basic textbook, he will find his work easier, more interesting, and on the soundest of foundations.

\section{RECENT ADVANCES IN GENITO-URINARY SURGERY}

By Hamilton Bailey, F.R.C.S., and Norman M. Matheson, F.R.C.S. J. \& A. Churchill, Ltd. 213 pages, 89 illustrations. Price 15/-.

The excellence of the "Recent Advances" series cannot be gainsaid, and the present volume is well up to the standard set by those which preceded it. It enables a busy surgeon to keep abreast with recent work done in this line, without having to search through the extensive literature on the subject. In this way much time is saved. In addition to the accounts of new work given in the text, which are usually sufficiently clear, a carefully selected bibliography is inserted at the end of each chapter. It forms an excellent starting point if one wishes to look up the complete literature on some debatable point.

The Authors rarely state their own opinions. They are usually content to quote those of recognised authorities, but when they do give an opinion it is always sound and practical. It is, however, curious to note that there is no mention of mandelic acid in the treatment of acute pyelitis, or of the pyelitis of pregnancy. In both these conditions it has a very marked and rapid action, though in the latter it may be necessary to empty the renal pelvis by means of a ureteric catheter. Omissions of this nature are trivial, and can hardly be avoided in a short survey of the many recent advances in urology.

On the whole, the book is strongly to be recommended. It is clear, concise and accurate. The matter is well arranged, and there is no repetition or over-lapping.

\section{A Manual of Public Health LABORATORY PRACTICE}

By Professor J. R. Currie and ContriBUtors. Edinburgh. E. \& S. Livingstone. 1936. 21/- net.

The Medical Officer of Health has now-adays to be an Admirable Crichton, conversant with the whole circle of the sciences, physical, chemical, biological, social economic, psychological. To help him at this difficult game, Professor Currie has brought out this manual of 360 pages an 169 figures dealing with the subjects of Chemistry, Bacteriology, Meteorology; Protozoology, Helminthology, and Entomology, the three last-named being contributed by A. G. Mearns, Margaret W. Jepps, and Robert A. Staig, respectively.

The result is an excellent volume for the purpose intended, namely, to be a guide to the student and practitioner of public health. The various processes and examinations are well set out and described, and the public health implications noted and discussed. The illustrations are also a feature.

The selection of subjects dealt with under Chemistry, might well be adopted by the revisors of the Curriculum for the Diploma in Public Health, and a thorough knowledge of the same demanded. But such a consideration raises the further question whether the intending medical student should not be required to arrive at age eighteen at the University, having already had a three years' course at a School or Technical College, in physics and chemistry; or otherwise precede his medical course with a science one including these subjects. It is impossible for the present 